\title{
Mythic Frodo and his Predestinate Call to Adventure
}

\author{
Farid Mohammadi \\ English Department \\ Islamic Azad University, Karaj Branch \\ 31485, Karaj, Iran \\ E-mail : safm27@yahoo.com
}

Received: 10-05-2013

doi:10.7575/aiac.ijalel.v.2n.5p.117
Accepted: 24-06-2013

Published: 01-09-2013

URL: http://dx.doi.org/10.7575/aiac.ijalel.v.2n.5p.117

\begin{abstract}
One of the most interesting aspects of J.R.R. Tolkien's stories, especially The Lord of the Rings is the presentation of the multidimensional characters; therefore, the complexity of interpretations concerning their actions, motives, and aims will be manifested from the beginning of the story, until the end. Following the study of a mythic hero's adventure, initiation, and psychological aspects, the present paper focuses on the investigation of Predestinate Call to Adventure. The researcher has benefited the theories of Joseph Campbell, presented in his renowned book The Hero with a Thousand Faces and the supplementary comments of Christopher Vogler. In fact, the researcher's motivation for the work initiated in this regard is to improve the very few previous attempts studied by others, concerning Frodo Baggins' role as the main and the most tragic hero of The Lord of the Rings.
\end{abstract}

Keywords: Mythology, Tragic hero, Mythic hero, Tolkien's legendarium, Monomyth, Initiation

\section{Introduction}

During the time, Tolkien was shaping and re-shaping his legendarium, and later on, while he was actually writing his Lord of the Rings, it is evident that he did not know anything about Joseph Campbell's systematic theory of monomyth or the hero's journey. On the other hand, Campbell himself did not know anything about Tolkien's newly created mythology and his mythic/heroic stories. Therefore, to consider that Campbell used the framework of Tolkien's story, as his role model and example, or vice versa, is completely inaccurate and far from truth. As a result, it would seem relevant to conclude that there was no relationship between Campbell's The Hero with a Thousand Faces [first published in 1943] with Tolkien's collection of works, whatsoever.

Campbell believed that every story and mythology, from all around the world has a similar system in its core; and that every heroic story has the same journey and consequences in its bones. Therefore, after years of analyzing different ancient folklores and mythologies from all around the world, he proposed his widely known term monomyth, a term he borrowed from James Joyce's Finnegans Wake. Moreover, he used the ideas of Jung's theory of Archetypes to find "the common underlying structure behind all religion and myth." Thereupon, Campbell raised a serious question, by asking, "Why is mythology everywhere, the same, beneath its varieties of costume?" ii

In his book, The Hero with a Thousand Faces, Campbell answered his own question, by saying, "Why some similar characteristics and attributes in fairytales, myths, and legends are so common around the world; the fact is, our minds and thoughts are so alike to each other, even though we have such a multitude of different cultures and [religions]." iii It is worth mentioning that as a Medieval specialist and Anglo-Saxon Professor, J.R.R Tolkien was constantly working on medieval texts, and his interest in Celtic, Germanic, Finish, Old Norse, Icelandic, and Greek mythologies was such, that he delicately borrowed some elements from those respected literature and cultures. In fact, he believed that he had not created and offered something new, however, he had managed to re-tell the ancient stories, in a new era. ${ }^{\text {iv }}$

To describe his systematic theory, Campbell introduces seventeen stages for the hero's journey. Very few stories embrace all the seventeen stages; in fact, some myths contain many of the phases, while others include only a few. On the other hand, some stories may focus only on one of the stages, concerning the specific framework of the story; while other myths may deal with some specific stages in dissimilar aspects, related to the incidents of the hero's path. These seventeen stages could be divided into three distinctive phases. The first phase is "Departure," [this phase is sometimes called Separation], the second phase is "Initiation," and the third and final phase is called "Return."

Heroes are introduced in the ordinary world, where they receive "The Call to Adventure" from a Herald, which they may accept or "Refuse the Call," however, they will be encouraged by a mentor to accept their Quest. "Supernatural Aid" comes, when the hero meets one or various entities, who appear in front of his heroic path, to help him with their supernatural gifts. Therefore, by crossing "The first Threshold," he enters the Special World, where they encounter Tests, Allies, and Enemies. The last stage of the "Departure" is called "The Belly of the Whale," which is the final approach to the Inmost Cave that leads to the journey's heart, and will be followed by Ordeals. The second phase is divided into six stages. The first one is "The Road of Trials." As a result, the hero will be faced with many ordeals and unpleasant experiences, henceforth, his magical items will be helpful to pass this particular stage. "The Meeting with the Goddess" is the second stage of Initiation, in which a mystical marriage takes place between the hero and a queenlike figure. The next stage is the "Woman as the Temptress"; in this situation, the hero is tempted to give up his Path, which would signify that he would be persuaded to relinquish his Quest. The fourth stage is the "Atonement with the 
Father," the hero will be faced with a father figure entity, who is simultaneously a tyrant, and a merciful figure. The fifth stage is called "Apotheosis," when the hero's central idea of reality will be changed and transformed. The hero may acquire a special ability, or his personality will be changed to be courageous enough to venture more deeply in his Quest; however, this process will be followed by the hero's self-sacrifice. The final stage of the second phase is called "The Ultimate Boon," where the hero is ready to receive what he came to obtain, hence he may be able to benefit his society or to earn a new perception and consciousness and that will be followed by the hero's escape from that place.

The third and final phase is divided into six stages, such as the "Refusal of the Return," "The Magic Flight," the "Rescue from Without," "The Crossing of the Return Threshold," "Master of the Two Worlds," and "Freedom to Live". Accordingly, one would expect that not all of the stages of monomyth, or the arrangement of the stages could be matched exactly with the framework and the processes of Tolkien's story. It should be noted that to study and prove Frodo's quest, which was a Predestinate Call to Adventure, the researcher intends to apply only the first two phases of Campbell's monomyth.

\section{Departure: The Call to Adventure}

According to Campbell's monomyth, before the Call to Adventure begins, the future hero lives with his few band of friends and family on a peaceful, quiet and untroubled realm, which is in many aspects, quite different from the outside world... The hero-to-be, the one, who is just a simple, often unpopular, and isolated figure, according to the opinion of the society in which he lives is not still considered as a stereotype "Hero," according to the traditional codes and signs, known to have belonged to the noble warriors of each community. The fascinating chain of reactions starts once the tensions of the outside world threatens the peaceful everyday life. In fact, the world around the hero is no longer like the past, anymore.

Now the strains, pressures, and horrors of the unknown outside world have reached the hero's pacific country; therefore, everything prepares him for the fateful meeting with the "Call to Adventure." The unlikely, down-to-earth hero of the Third-Age of Middle-earth in the Lord of the Rings, comes from a small district in Eriador, called the Shire. In many aspects, Frodo's figure fits perfectly with Campbell's model of the "unlikely hero." He was considered as one of the young rascals of Buckland. " Most people would look at him suspiciously, rather than like their friendly fellow Hobbit, for he is an "elf-friend," and a traveler; moreover, because of his family roots, he was not so popular among his people.

When Frodo received the One Ring from his uncle Bilbo, and later Gandalf recognized it as the Evil One Ring, the frightening and strange events were set in order to begin the adventure. Campbell says, "The familiar life horizon will be outgrown; the old concepts, ideals, and emotional patterns no longer fit; the time for the passing of a threshold is at hand..." vi "This is the moment that destiny, in contrast to the other's image of an idol hero, summons the Hero."vii

Moreover, Christopher Vogler believes that, "The Call to Adventure may come in the form of a message or a messenger. It may simply be a stirring within the hero, a messenger from the unconscious, bearing news that it is time for change. These signals sometimes come in the form of dreams, fantasies, or visions. "viii

Therefore, out of the young Hobbit's expectation, the Call to Adventure began. Gandalf asked Frodo to keep the Ring, and wait for his call; however, Frodo reluctantly saw himself on a frightening and dangerously dark path, which was beyond the power of a halfling. He could no longer remain passive and indifferent towards the frightening situation, and keep on living in the comfort of the ordinary world... "Perhaps the land is dying" ix [and in Frodo's case, the whole Middle-earth was on the verge of destruction]. Every invitation and Call to Adventure needs a Herald to appear in the scene, and provide hearty motivation, by offering the hero a challenge to get the story rolling, as one would say. He alerts and announces the hero the outcoming change; therefore, adventures are on their way to reach him ${ }^{\mathrm{x}}$. For this reason, we see Gandalf the Grey, playing the important and crucial role of the Herald. Campbell believes that this figure appears at the begging of the story, so that the hero, along with the reader comes to understand the end of an era, and the beginning of a new phase.

Gandalf is indeed, one of the most powerful figures in the Third-Age of Middle-earth, who was very famous among the people of each race, and whom, people found as a troublemaker sometimes. That came from their imperfect and defective knowledge of him. It seems that he was aware of everything and everyone around him, and beyond him. Therefore, as the reader follows the sequences, one after the other, he would understand that the first stage is already finished. The unlikely hero finds himself in a new phase, and he already knows that he is the chosen one; however, he is not comfortable with his quest. He sees his acceptance to the Call, as a temporarily mission; and he desperately hopes to release himself from that inevitable and predestinate Call, which is in fact, an inescapable task to fulfill.

\section{Refusal of the Call}

In fact, Refusal of the Call happens when the hero finds himself at the beginning of a dangerous Path. In this stage, the most disturbing issue for him is his flawed and blind perspective toward his fatalistic mission; he does not know at all, whom he shall encounter, and how he should behave before various events. Furthermore, he has no idea at all, in what sense he may be able to complete his journey.

In this stage, the negative aspects of the unknown leads him to relinquish his previously accepted Call to Adventure, for he is not yet fully committed to his Odyssey, and not yet ready for the sudden changes. Moreover, he would need the mentor's motivation, fortification, and spiritual encouragements, ${ }^{x i}$ [and we know that the mentor is none other than Gandalf]. Vogler says, "It's natural for heroes to first react by trying to dodge the adventure. Even Christ, in the Garden of Gethsemane on the eve of the Crucifixion, prayed, "Let this cup pass from me." xii

Consequently, the previous instances could be detected in Frodo's case, when Gandalf describes how he should destroy the One Ring. He says. "There is only one way: to find the Cracks of Doom, in the depths of Orodruin, the Firemountain, and cast the Ring in there, if you really wish to destroy it, to put it beyond the grasp of the Enemy forever..." 
However Frodo replies, "I do really wish to destroy it!" cried Frodo. "Or, well... to have it destroyed. I am not made for perilous quests. I wish I had never seen the Ring! Why did it come to me? Why was I chosen?"

"Such questions cannot be answered," said Gandalf. "You may be sure that it was not for any merit that others do not possess: not for power or wisdom, at any rate. But you have been chosen, and you must, therefore, use such strength and heart and wits as you have." xiii

Frodo, thus, makes excuses to escape from that dreadful task, however, he is unable to persuade Gandalf; therefore, he tries another way, which is to offer the Evil Ring to Gandalf himself.

"But I have so little use of any of these things! You are wise and powerful. Will you not take the Ring?"

"No!" cried Gandalf, springing to his feet. "With that power, I should have power too great and terrible! And over me, the Ring would gain a power still greater and more deadly."

Although Gandalf possessed vast Knowledge like Saruman, nevertheless, unlike him he was blessed with wisdom; this is why he resisted against the temptation of accepting that Dark and frightening Ring for himself.

At this time, the old friendly relationship between Gandalf and Frodo is changing inevitably, to become a relationship between a hero and his mentor. In regard to this specific situation, Vogler adds, "By this time, many stories will have introduced a Merlin-like character, who is the Hero's Mentor. The relationship between the Hero and the Mentor is one of the most common themes in Mythology, and one of the richest, in its symbolic value. It stands for the bond between parent and child, teacher and student, doctor and patient, god and man." ${ }^{\mathrm{xv}}$

\section{Crossing the First Threshold}

After the second stage, the Supernatural Aid comes. It is worth mentioning that, in order to place Frodo in the scale of monomyth, the arrangements of some of the Campbellian stages need to be changed. ${ }^{\text {xvi }}$ As a result, in Frodo's case, the supernatural aides come, once he passes the first Threshold and not after the Refusal of the Call. By leaving the Shire to enter the unknown lands along with Sam, Merry, and Pippin, Frodo actually abandons his old life and his safe realm, to initiate his journey. Here, Campbell says. "The hero leaves his familiar surroundings, in crossing the First Threshold, and steps then into the Unknown, where Dark Forces and Mortal Perils lie, in wait... xvii

Anne C. Petty believes that the First Threshold starts from the Old Forest, and reaching into Rivendell; ${ }^{\text {xvii }}$ however, while the Old Forest was a dangerous, unknown, and unfriendly place, Rivendell was not at all something that one would expect as stepping into darkness. Moreover, Frodo was not even sure about his quest yet, and he thought of his mission as a temporarily responsibility. Furthermore, by Threshold, one tends to imagine a dark forest, where shadows and terror lie and everything seems to threaten the hero and his friends... In contrast, Rivendell is one of the few remaining safest places of Middle-earth, during the Third-Age, where Elrond and his fellow elves still live in it.

According to Christopher Vogler, "it is a place that the hero, having overcome fear, has decided to confront the problem and takes action. He is now committed to the journey and there is no turning back." xix "He fully enters the Special World of the story for the first time, by crossing the First Threshold. He agrees to face the consequences of dealing with the problem and/or challenge, posed in the "Call to Adventure." ${ }^{x x}$ Therefore, in Frodo's case, this is the moment when the story takes off, and the adventure really gets going. By considering Vogler's definition of the First Threshold, one would assume that when Frodo accepted to be the Ring-bearer, the necessary determination and commitment to initiate the heroic Path will start precisely from this point onward. In fact, the consequences of his decision really take place, when he and the fellowship abandon Rivendell, to enter, and then cross the First Threshold.

\section{Supernatural Aid}

The Supernatural Aid can be manifested to the hero, by both masculine and feminine figures. At this point, out of his expectation, the hero will receive help and assistance in the most critical situation, and in a very dangerous realm, where the hero metaphorically can smell magic in the air, which leads to his unavoidable confrontation with powerful negative forces.

According to Campbell, when the hero intends to pursue the journey, a protective figure, mostly in the shape of an old man will accompany the hero to help him in his critical moments, ${ }^{\text {xxi }}$ just as Old Merlin helped King Arthur. However, Campbell continues to say that this figure does not always appear as an "old crone,"xxii it can also be manifested as the most, or one of the most beautiful earthly or otherworldly figures in the stories. Sometimes, this entity manifests itself as a feminine figure in Western Literature, especially in Christian themes; this entity is often shown through the Blessed figure of the Virgin Mary, who rescues Saints or common people. In this regard, Campbell had explained. "The hero, who has come under the protection of the Cosmic Mother, cannot be harmed." xxiii

In The Lord of the Rings, there are different examples of help and assistance to the hero and his friends. Some experts and critics believe that every "helper" of Frodo can be included in this specific category. However, as the title of this stage suggests, it should be noted that not all of these examples could be included in this category, mainly because of two important matters, which shall be explained consequently. The first reason is that the helper should have magical, spiritual, and mystical powers, while the second reason is that the helper's responsibility is to assist and guide the hero, through his Journey, not trying to mislead him in his path. Supernatural Aid could be considered as a gift of destiny to the hero, for his deep commitment to his mission. As a result, it would appear as a false hypothesis, if one includes a figure such as Gollum as the role of a helper, who offers his supernatural aid to Frodo and Sam. First, he does not have any supernatural powers, but only vile hypocrisy, duality, and greed. He is also the classical model of he, who deceits and misleads the hero. However, although a part of Gollum wants to be good to his temporary master [Frodo], but he is indeed an enemy, who was wearing the mask of an ally. Gollum is in fact, one of the most interesting characters to study, if one wishes to conduct research, into the concept of contradictory duality, ${ }^{\text {xiv }}$ shown through his confrontation with his own shadow. In spite of this, at the end he finally saves everyone in the Middle-earth, by biting off Frodo's finger; however, he cannot be included in this category because of the essential avidity that he was afflicted. 
The second false example is Faramir. Although once he came to know of the two Hobbits' mission, and advised them about several matters, such as to be wary of Gollum and about their destination as well. However, once again, when a helper should be endowed with magical powers, he was devoid of any such powers, and according to Campbell's definitions, one would expect more of these helping figures to offer, to be included in this category.

In fact, the most appropriate and fitting personality, who can be included in this category begins with Gildor Inglorion, one of the Noldor, and a leader of the elves in exile. He met Frodo and his Hobbit friends in the Shire, by keeping them unharmed from Black Riders; thus, he can be included in this category. Gildor, though, did not give Frodo any precious and magical gifts; however, as the elves are usually associated with magical and supernatural powers, his oldness and his protection let him be included as one of the helpers.

The other example comes when Frodo and his Hobbit friends penetrated inside the ancient and unfriendly Old Forest, when the Old Man Willow, a grey thirsty spirit ${ }^{\mathrm{xxv}}$ swallowed Pippin completely, while at the same time, Merry's legs were soon to be swallowed altogether, and Frodo and Sam shouted desperately for help. In that moment, Tom Bombadil, an ancient entity of the Old Forest came and released them from that dark entity by singing, and thus helped the Hobbits. In another instance, he rescued them from the evil Barrow-wight. Therefore, Tom Bombadil, fits completely and most convincingly the role of a helper with Supernatural Aid. He not only saved and helped them, but also taught them a song and gave them daggers.

Glorfindel [golden-haired], one of the ancient and powerful Firstborns, a valiant Elf Lord and almost an equal to the Maiar ${ }^{x x v i}$ came to help Frodo across Rivendell. Ringwraiths, who were afraid of his might and power could thus, not pursue Frodo and his companions anymore. Another helper is Frodo's uncle Bilbo, who was 128 years old and a very old Hobbit indeed. This is because of the Ring's Magic that his life stretches on. Personally, he does not possess any magical powers, but he gave Frodo some magical gifts, such as the precious elven-sword, called Sting that shines in the dark, when the Orcs are around the sword-bearer; and a mithril-coat, known as the true silver, found only in the farthest reaches of the mines of Moria. Undeniably, these precious gifts saved Frodo's life in numerous instances.

Galadriel, known as the Lady of Lothlórien is another crucial character, who serves as the helper with supernatural aids. Galadriel is the rightful possessor of the Elven ring Nenya, and one the most powerful, and most important elves of Middle-earth, who actually may symbolize the Holy Figure of the Virgin Mary, ${ }^{\text {xxvii }}$ according to some highly accredited critics. This beautiful, radiant elf-lady is the "greatest of the Elven women, proud, strong, and self-willed." xxviii She gave appropriate gifts to each member of the fellowship and offered Frodo the light of Eärendil's Star, which is the last surviving Silmaril, in a small phial. She said, "May it be a light to you in dark places, when all other lights go out..." xxix She also provided him with a cloak of invisibility that could keep its wearer invisible, safe and out of sight from hostile eyes. Moreover, she presented elven magical ropes, and Lembas [wegbræde], as the way-bread of the elves, to each member of the fellowship.

Although in many different occasions, Gandalf and Aragorn contributed a lot for the sake of Frodo to stand firmly and bravely against the Dark Armies, however, both served only as the temporary guides, who did not present any magical gifts to the Ring-bearer.

\section{The Belly of the Whale}

The idea of the passage to the Magical Threshold has been described as a transfer into a Sphere of Rebirth. It is symbolized in the worldwide images of the womb and the belly of the whale. The hero, instead of conquering or conciliating the power of the Threshold is swallowed into the unknown and appears to be dead. ${ }^{\mathrm{xxx}}$ On her critical interpretation of Frodo, Anne C. Petty did not study and include this stage on Frodo's journey; however, Tutta Kesti ${ }^{\text {xxxi }}$ has mentioned three examples for this stage. Accordingly, it is perhaps possible to mention Frodo's entrapment under the ground, by the "Barrow-wight," and then, when he was stabbed by the Witch King of Angmar, and finally in the Shelob's lair, where he was deeply stung by the evil offspring of Ungoliant, as the examples of this stage. Frodo nearly died in all those three examples, previously mentioned; and when he regains his life force, once again, it symbolizes as a "Rebirth" and a new life for him. In fact, concerning this stage, Campbell says, “... instead of passing "outward”, and beyond the confines of the visible world, the hero goes "inward"; this disappearance corresponds more to the entrance of a worshiper inside a temple. The temple, the inner quality, the belly of the whale, and the heavenly land beyond, above, and below the confines of the world, are the same. That is why the approaches and entrances to temples are protected and defended, by colossal Gargoyles, such as dragons, lions, devil-slayers with drawn swords, resentful dwarfs, and winged bulls." xxxii

According to Campbell's definition in this specific stage, it is perhaps fair to believe that Frodo's use of the One Ring and his disappearance from the eyes of the others, followed by his entrance to a kind of inner dimension is another example for The belly of the Whale. In fact, although this dimension is rather metaphysical than physical, nonetheless, its significance and effect on the hero does not violate Campbell's term. In fact, by wearing the One Ring, Frodo enters a dimension where Sauron sees him and thus, Frodo unwillingly attracts his attention and that of his servants, which is tragic and shall bear its own painful consequences in the next stages of his Journey.

\section{Initiation: The Road of Trials}

Campbell explained that, "Once, having passed the Threshold, the hero moves in a dream landscape of curiously fluid, ambiguous forms, where he must survive a succession of trials. This is the favorite phase of the Myth Adventure. The hero is covertly aided by the helper's advices, and secret agents of the supernatural helper, whom he met before his entrance into this region, or it may be that here, he discovers for the first time that there is a benign power, everywhere around him, supporting him in his superhuman passage." xxxiii

The Road of Trials for Frodo starts when Gandalf recognizes the One Ring and asks him to leave the Shire and ends in Mordor, in the cracks of Mount Doom, where he suddenly willed to keep the Evil Ring for himself. During all these 
events, incidents, and sequences, Frodo was supported and assisted, by his fellowship and ancient powerful entities; even Gollum was at his disposal for a very short time, until he deceived Frodo, by leading him to the Shelob's lair. Only Frodo and Sam knew that Frodo did not fulfill his painful task to the end, and that it was Gollum, his double, ${ }^{\text {xxxiv }}$ who terminated Frodo's Mission.

Other characters, such as Gandalf, Aragorn, Legolas, Gimli, Boromir, Faramir, Bilbo, Sam, Merry, Pippin, Elrond, Galadriel, Arwen, Glorfindel and Tom Bombadil influenced and helped the hero directly or indirectly with their swords, advices, guidance or their precious gifts, such as the Mithril-coat, the Sting, the Phial, the Cloak, lembas, hithlain ${ }^{\mathrm{xxx}}$, and even a magical song. However, it is worth mentioning that there are also some other characters, who stood against Sauron, the Melkor's chief servant and played a significant role in the Greatest Battle of the Third-Age of Middle-earth.

\section{The Meeting with the goddess}

When Frodo and his companions reached Lothlórien and met Galadriel, the Lady of Lothlórien, she actually fits the role of the hero's goddess. Interestingly, Campbell describes the characteristics of the goddess, by saying, "She encompasses the encompassing, nourishes the nourishing, and is the life of everything that lives. She is also the death of everything that dies. She is the womb and the tomb; thus, she unites the "good" and the "bad," exhibiting the two modes of the remembered mother, not as personal only, but as universal. The devotee is expected to contemplate the two, with equal equanimity. Through this exercise, his spirit is purged of its infantile, inappropriate sentimentalities and resentments." xxxvi

The hero is destined, therefore, to meet the one who shall guide him firmly through his initiation. Soon after the Council of Elrond, Frodo meets Galadriel, one of the ancient and powerful Elves of Middle-earth. Perhaps the friend of Melian was the greatest of the Noldor, except Fëanor. ${ }^{\text {xxxvii }}$ It is she, the preserver, healer, and protector of the nature of her realm. The Lady of the Galadrim is the one, who first summoned the White Council, "If my designs had not gone amiss, it would have been governed by Gandalf the Grey, and then mayhap, things would have gone otherwise." xxxviii Galadriel is certainly and undoubtedly very important, not only as a queen among Elves, but as shrewd shaper and wise planner; she is the astute mastermind of the greatest things in Middle-earth, affecting not only her people, but also the people from other races. She did, in fact, what she had meant to do; she passed the test, guided the Ring-bearer, and even offered them precious elvish gifts. Campbell even hinted that sometimes, the hero marries the goddess, but in this particular story, this concept does not exist and thus, cannot be discussed, any further.

\section{Woman, as the Temptress}

As it has been explained previously, very few myths cover all of the stages of monomyth. Some stories include many of the stages, while some others only a few. In fact, one of the powerful aspects of Campbell's monomyth is its flexibility and depth, which opens the door for various interpretations and the possibility of changing its primary definition. As a result, if one may apply Campbell's Monomyth, in relation to Frodo's Quest, it is necessary to study this specific stage with different angles.

In this step, the hero is confronted with earthly temptations, such as physical desires or the possibility of appropriating personal power, which may force him to abandon his Quest. Therefore, the concept of temptation does not necessarily have to be shown by a woman. Here, the concept of "woman" is a metaphor for the physical and/or material temptations of life. In fact, Frodo's scenario is different; no temptation occurred by a woman, to urge him to give up his Quest, or during his meeting with the goddess [who is Galadriel], he did not confront a strong, lustful, and irresistible temptation. Therefore, it would be appropriate to change the title of this stage to "Temptation, as an operative factor" in front of the hero's Path.

Temptation is one of the most important focal points in Tolkien's legendarium. Although in this stage, someone should come along and tempt the hero, so that he may give up his mission, however, in Frodo's case, one may well consider another scenario: as a Ring-bearer, Frodo acted in some way as a tempter himself. At the beginning of the story, he decided to give up the One Ring, that is why he offered it to Gandalf, and in some other point in the story, he offered it to Galadriel.

In this point of the story, Gandalf says, "A Ring of Power looks after itself, Frodo. It may slip off treacherously, but its keeper never abandons it. At most, he plays with the idea of handing it on to someone else's care - and that only at an early stage, when it first begins to grip. But as far as I know, Bilbo alone in history has ever gone beyond playing, and really done it. He needed all my help, too. Even so, he would never have just forsaken it, or cast it aside. It was not Gollum, Frodo, but the Ring itself that decided things. The Ring left him." xxxix

"The Ring was trying to get back to its master. It had slipped from Isildur's hand and betrayed him... So now, when its master was awake, once more, and sending out his dark thought from Mirkwood, it abandoned Gollum." xl

"And over me, the Ring would gain a power, still greater and more deadly." His eyes flashed and his face was light as by a fire within. "Do not tempt me! For I do not wish to become like the Dark Lord himself. Yet, the way of the Ring to my heart is by pity, pity for weakness and the desire of strength to do good. Do not tempt me! I dare not take it, not even to keep it safe, unused. The wish to wield it would be too great, for my strength. I shall have such need of it. Great perils lie before me." xli

These examples show how dreadful and powerful was the Ruling Ring. Gandalf more than once repeats. "Do not tempt me!" or for that matter, when Frodo offers the Ring to Galadriel, she says in her turn, "I do not deny that my heart has greatly desired to ask what you offer. For many long years, I had pondered what I might do, should the Great Ring come into my hands, and behold! It was brought within my grasp. . . And now at last, it comes. You will give me the Ring freely! In place of the Dark Lord, you will set up a Queen; and I shall not be dark, but beautiful and terrible, as the Morning and the Night! Fair as the Sea and the Sun and the Snow upon the Mountain, dreadful as the storm and the lightning; stronger than the foundations of the earth! All shall love me, and despair!" xlii 
However, she is wise enough to know the dangers of such mortal, gloomy power. Concerning the sinister and treacherous power of the Ring, it can be said that Frodo, as the hero was changed and transformed by the Ring's will, and acted as a mediator agent, and a compulsive entity to serve for the greater desire of the Ring and its Lord. It is perhaps possible then to assume that the Ring wanted "to be offered" to one of the most powerful and greater figures in Middle-earth, so that the Dark Lord may be able to achieve his final will, which was to rule them all! Just like the last time, when he gave nine Rings to kings of men, who faded; and then came under his dominion, as the Nazgûl [Ringwraiths]. In those cases, both Gandalf and Galadriel resisted and passed the test; in fact, unlike Saruman, who had been deceived by Sauron via an ancient Palantir, they stood against the Ring's temptation, offered to them via Frodo.

The other example is the hero himself, who most tragically was deceived at the end of his initiation, when he stood on Sammath Naur [The Chambers of Fire, inside Mount Doom]; a place, where he should have destroyed the Ring; instead, he said, "I have come but I do not choose now to do what I came to do. I will not do this deed. The Ring is mine!" xliii In addition, this leads to his climatic Apotheosis.

\section{Apotheosis}

Although Campbell arranged Atonement with Father, before the Apotheosis, however, in Frodo's case, this stage did not happen actually. Frodo's Apotheosis happens, instead, in the cracks of Mount Doom, where he came to cast the Ring inside the blazing Fire. Instead, he suddenly changed his mind, and decided to keep the Ring. Especially, by taking note that Frodo's mission and aim was not to achieve something worthwhile and precious [at least, in Gollum's eyes!] but to destroy and/or give up something.

From the beginning of the story, until the end at the cracks of Mount Doom, the responsibility of bearing the "One Ring" was a torture and a torment for Frodo, and he was always afraid of using the Ring. However, Frodo fell, metaphorically, in the Valley of Perdition and thus, claimed the Ring for himself. The Ruling Ring had finally reached its birthplace, its root, its foundation: Mount Doom, a hellish and sinister place, where the Ring has its ultimate Evil Power. Frodo is going to accept his dark side's invitation to break the boundaries of morality, and relinquish himself from the heavy burdens of being a good person, as others had expected him to be. Now, tired of listening to his superego, and the characters, which act as such, or reminding him of it, [people such as Gandalf and Sam, for instance], he finally broke the boundaries. Why should he always listen to the others, he asked himself? Was there anyone else among his friends, to bear such pains and tortures? He was wounded both, with a sword and a sting; was that not enough, already? Therefore, did he not deserve, for once, to listen to his own wish? Did he not deserve to have his own Free Will? Was it not enough to bear the Ring, until that moment? Therefore, tired and frustrated, Frodo declares at last, "I have come, but I do not choose now to do what I came to do. I will not do this deed. The Ring is mine!" According to Campbell, "The childhood parent images and ideas of "good" and "evil" have been surpassed. We no longer desire and fear. We are what was desired and feared." xliv

Sauron had transferred much of his Power in the Ring; that is why the Ring was so frightening, dangerous, and deceitful at the same time... Thus, by claiming the Ring as his own, Frodo chooses the Dark Path, and by wearing the Ring, it is his way of performing the ritual of "Comitatus" before the Dark Forces. It seemed that Frodo intended to become the next Dark Lord himself... He is no longer afraid of doing what he desires most! He no longer wishes to follow the authorities, but decides to be the Supreme Authority, therefore, why not be "The One"? At last, the Ring made him become like his shadow figure [Gollum]... ${ }^{x l v}$ The Evil Artifact of Sauron, the chief servant of Morgoth justifies its legitimate use, by Frodo. By wearing the Ring, Frodo vanishes into air, and thus, achieves his Apotheosis...

Indeed, when Gollum bit off Frodo's finger and fell into the Cracks of Doom, he not only gave Frodo Baggins the greatest favor, but he also offered it to the entire Middle-earth and its people. That is why Tolkien had suggested that Frodo was "inevitably predestined" to receive the Ring, "You also were meant to have it." xlvi Consequently, the Ring goes back to its mother's womb [that is: the Fire, inside the Mount Doom] instead of its Father ${ }^{\text {xlvii }}$ [Sauron], and for that matter, the Ring is destroyed, as well as its sinister and gloomy Father. As a result, the hero is "the twice-born. And he is competent, consequently, now, to enact himself the role of the initiator, the guide, the sun door, through whom, one may pass from the infantile illusions of "good" and "evil" to an experience of the majesty of cosmic law, purged of hope and fear, and at peace, in the understanding of the revelation of being. ${ }^{\prime \prime \prime l v i i i ~}$

Middle-earth was then saved from a Dark Terror, first because of Bilbo Baggins's pity and later on, because of Frodo's pity that caused both of them, to show mercy and compassion towards that pathetic creature, doomed to die anyway, in that most tragic way. Indeed, the heavy burden of being the hero does not always require being skillful in using weapons or casting magical spells, while practicing all kinds of supernatural powers. Thus, as a devoted Catholic, Tolkien establishes the inevitable truth that even in an ancient world, called Middle-earth, where powerful and terrifying Dark Forces existed, there was a simple, down to earth "Halfling," called Frodo Baggins of the Shire, who saved and redeemed the world from the Dark Lord Sauron, known as the greatest terror of the Third-Age. Moreover, he accomplished his mission, only by the power of his "pity and mercy."

Interestingly enough, throughout the story, the reader observes Sam's hatred, toward Gollum, for Sam clearly maintained and insisted always that it was far better for both Frodo and him to kill Gollum, and be done with him. However, if they had done that or if Bilbo, in the past, had killed Gollum, when he had that opportunity, who would have then bitten off Frodo's finger, and destroyed the "One Ring" in that precise and fatal moment of the story...? Is it possible to assume that Gollum played his part, just as Destiny had willed him to play it? Just as Judas Iscariot played his part in the Crucifixion of Jesus, so that God's Will may be accomplished, and the Original Sin be forgiven...?

More than two thousand years ago, Saint Luke had repeated in the same way, Jesus' words to Humanity, "I say unto you, Love your enemies, do good to them, which hate you. Bless them that curse you, and pray for them, which despitefully use you...For if ye love them, which love you, what thank have ye? For sinners, also, love those that love them. And if ye 
do good to them, which do good to you, what thank have ye? For sinners, also, do even the same. And if ye lend to them, of whom ye hope to receive, what thank have ye? For sinners, also, lend to sinners, to receive, as much again. But love ye, your enemies, and do good, and lend, hoping for nothing again; and your reward shall be great, and ye shall be the children of the Highest: for He is Kind unto the unthankful and to the evil. Be ye therefore merciful, as your Father also is Merciful." xlix

\section{The Ultimate Boon}

The last stage of Initiation is The Ultimate Boon. Now the Mission is accomplished, and it is time for the hero to leave the special world. Campbell says, "The ease with which the adventure is here accomplished signifies that the hero is a superior man, a born king." 1

Vogler believes that, "With the crisis of the Ordeal passed, heroes now experience the consequences of surviving death. With the dragon that dwelt in the Inmost Cave slain or vanquished, they seize the sword of victory and lay claim to their Reward. Triumph may be fleeting but for now they savor its pleasures.

We Seekers look at one another with growing smiles. We've won the right to be called heroes. For the sake of the Home Tribe we faced death, tasted it, and yet lived. From the depths of terror we suddenly shoot up to victory. It's time to fill our empty bellies and raise our voices around the campfire to sing of our deeds. Old wounds and grievances are forgotten. The story of our journey is already being woven. You pull apart from the rest, strangely quiet. In the leaping shadows you remember those who didn't make it, and you notice something. You're different. You've changed. Part of you has died and something new has been born. You and the world will never seem the same. This too is part of the Reward for facing death. "li

As a result, the hero's triumphant victory leads to the complete destruction and demolition of the enemy. Campbell says, "the miracle of miracles was that though all exploded, all was nevertheless thereby renewed, revivified, and made glorious with the effulgence of true being." lii In this place, the hero is ready to gain what he came to obtain, so that he may be able to benefit his society. In numerous examples, the hero will gain something powerful and precious; but in some other stories, the hero will only gain a new consciousness or comes to realize that there are so much more to understand than what it appears and thus, a new awakening or realization of something new will be manifested in his world-view.

Sauron was annihilated for the very fact that his evil Ring had been destroyed. The destruction of the Dark Lord leads to the devastation of Barad-dûr, his infernal symbol and his hellish tower as well. The greatest servant of Morgoth turned to some black clouds, and was blown away by a fresh, pure, and rejuvenating wind of the West. Therefore, after the departure of the Lord of the Rings from Middle-earth, everything appears to be born again and rejuvenated. Indeed, the day the destruction of the Ring took place, a new Era and Age had begun. As a result, one could accept that Frodo's Mission to save the Middle-earth, from the dark terrors of Sauron, was the most precious gift that a hero can accomplish at the end of his heroic Journey.

"Well, this is the end, Sam Gamgee," said a voice by his side. And there was Frodo, pale and worn, and yet himself again; and in his eyes there was peace now, neither strain of will, nor madness, nor any fear. His burden was taken away. There was the dear master of the sweet days in the Shire."

"Master!" cried Sam. and fell upon his knees. In all that ruin of the world for the moment, he felt only joy, great joy. The burden was gone. His master had been saved; he was himself again, he was free."liii

\section{Conclusion}

The Medievalist Tolkien had observed keenly about his beloved country's shortcoming in the matter of having any kind of English Mythology, in comparison with Celtic, Germanic, Finish, Old Norse, and Icelandic Mythologies; he intended therefore, to create and leave to posterity, a long-lasting legacy for his country liv. Tolkien's attempt, not only rehabilitated the public attention to the Fantasy worlds, "Faery-tales", and Mythological figures, but also filled and fulfilled the barren souls of the unfortunate people during wartime, by attracting their attention to rediscovering the existence of Hope, Faith, Chivalric manners, Pity and Mercy. In fact, Tolkien believed that it was the moral duty of Man, to "assert the existence of the good and true, to seek truth through myth, to exercise his God-given function of subcreation." "lv

Worthy of reflection is Campbell's strong and systematic approach to all ancient folklores, belonging to every corner of the world. Therefore, not only his mythic system opened up new dimensions to evaluate and dissect the stories most thoroughly and meticulously, but it also introduced new strategies for the way and manner of characterization of heroic figures. Indeed, by applying Campbell's comprehensive theory of the hero's journey to Frodo, Gandalf, Aragorn, Sam, and other characters from Tolkien's legendarium would achieve some interesting results within two special categories. The conclusion the researcher came to in his analysis is to recognize how thoughtful and helpful was Campbell's efforts in making a descriptive system of understanding the hero's journey, instead of a prescriptive system, which solely manifests itself, as a conventional solution and recipe. That is why Vogler says, "The Hero's Journey model is a guideline. It is not a cookbook recipe or a mathematical formula to be applied rigidly to every story. To be effective, a story does not have to concur with this or any other school, paradigm, or method of analysis. The ultimate measure of a story's success or excellence is not its compliance with any established patterns, but its lasting popularity and effect on the audience. To force a story to conform to a structural model is putting the cart before the horse. It is possible to write good stories that do not exhibit every feature of the Hero's Journey. "'vi

In fact, Campbell's hypothesis describes what is present in myths and ancient folklores of Man in every corner of the world, by analyzing the similarities between ancient heroic stories and Faery-tales. Secondly, by appreciating the way Tolkien had reinvented and reimposed the ancient mythic heroes, -with how much delicacy, elegance, and mastery-, and the way he re-told the ancient stories, by following Campbell's sources, which were the great myths, legends, and fairy 
tales of Western Europe through his sub-creation was outstanding, indeed. In fact, Campbell and Tolkien were unaware of each other's thoughts and literary concepts; nevertheless, much can be gained, by reading them both together. Christopher Vogler states that, "When we writers apply the ancient tools of the archetypes and the Hero's Journey to modern stories; we stand on the shoulders of the mythmakers and shamans of old. When we try to heal our people with the wisdom of myth, we are the modern shamans" lvii

\section{References}

Agøy, N.I. (Ed.). (1997). Between Faith and Fiction: Tolkien and the Powers of His World. Oslo: The Tolkien Society of Norway.

Bernard, I. (1909). Sermons of St. Bernard on Advent and Christmas: Including the famous treatise on the incarnation called "Missus est". London: R.T. Washbourne.

Birzer, B. (2003). J. R. R. Tolkien's Sanctifying Myth: Understanding Middle-earth. Wilmington: Isi Books.

Birzer, B. (2001). The Christian Gifts of J.R.R. Tolkien, New Oxford Review 68, no. 10 , 25-29.

Blackwelder, R. E., Hammond, W. G., \& Scull, C. (2006). The Lord of the rings, 1954-2004: Scholarship in honor of Richard E. Blackwelder. Milwaukee, Wis: Marquette University Press.

Bloom, H. (Ed.). (2000). J.R.R. Tolkien. (Modern Critical Interpretations).Philadelphia: Chelsea House Publishers.

Bloom, H. (Ed.). (2000). J. R. R. Tolkien's Lord of the Rings (Modern Critical Interpretations). Philadelphia: Chelsea House Publications.

Boyd, I., \& Stratford C. (2003). A Hidden Presence: The Catholic Imagination of J.R.R. Tolkien. New Jersey: Chesterton Press.

Burns, M. J. (2005). Perilous Realms: Celtic and Norse in Tolkien's Middle-earth. Toronto: University of Toronto Press. Caldecott, S. (2005). The Power of the Ring: The Spiritual Vision Behind "The Lord of the Rings". New York: Crossroad Publishing Company.

Caldecott, S. ( 2003). Secret Fire: The Spiritual Vision of J.R.R. Tolkien. London: Darton, Longman, and Todd.

Caldecott, S., \& Morrill, J. S. (1997). Eternity in Time: Christopher Dawson and the Catholic Idea of History. Edinburgh: T\&T Clark.

Campbell, J., Kudler, D., Joseph Campbell Foundation. (2004). Pathways to bliss: Mythology and personal transformation. Novato, Calif: New World Library.

Campbell, J. (1968). The hero with a thousand faces. Princeton, N.J.: Princeton University Press.

Campbell, J., Cousineau, P., Brown, S. L. (2003). The hero's journey: Joseph Campbell on his life and work. Novato, Calif: New World Library.

Carpenter, H. (1977). The Authorized Biography of J.R.R. Tolkien. London: Allen \& Unwin.

Carpenter, H. (1979). The Inklings: C. S. Lewis, J.R.R. Tolkien, Charles Williams, and Their Friends. Boston: Houghton Mifflin.

Carpenter, H. (1981). The Letters of J.R.R. Tolkien. London: Allen \& Unwin.

Chance, J. (1992). The lord of the rings: The mythology of power. New York: Twayne Publishers.

Chance, J. (2001). Tolkien's Art: A Mythology for England. Lexington: University Press of Kentucky.

Chance, J. (Ed.). (2003). Tolkien the Medievalist. London; New York: Routledge.

Croft, J. B. (2004). War and the works of J.R.R. Tolkien. Westport, Conn: Praeger.

Drout, M. D. C. (Ed.). (2006). J. R. R. Tolkien Encyclopedia: Scholarship and Critical Assessment. New York City: Routledge.

Duriez, C. (2001). Tolkien and the Lord of the Rings: A guide to Middle-earth. Mahwah, N.J: HiddenSpring.

Ellwood, R. S. (2002). Frodo's quest: Living the myth in The Lord of the Rings. Wheaton, Ill: Quest Books.

Flieger, V. (2002). Splintered Light: Logos and Language in Tolkien's World. Kent, OH: Kent State University Press.

Flieger, V. (2005). Interrupted music: The making of Tolkien's mythology. Kent, Ohio: Kent State University Press.

Flieger, V., \& Hostetter, C. F. (2000). Tolkien's legendarium: Essays on The history of Middle-earth. Westport, Conn: Greenwood Press.

Kesti, T. (2007). Heroes of Middle-Earth : J. Campbell's monomyth in J. R. R. Tolkien's The Lord of the Rings (19541955). Finland: University of Jyväskylä.

Kerry, P. E. (2011). The Ring and the Cross Christianity and the Writings of J.R.R. Tolkien. UK: Fairleigh Dickinson University Press.

Kocher, P. H. (1985). Ilúvatar and the Secret Fire. Mythlore: A Journal of J. R. R. Tolkien, C. S. Lewis, Charles Williams, and Mythopoeic Literature. 12.1, 36-37.

Kocher, P. H. (1972). Master of Middle-earth: The Achievement of J.R.R. Tolkien. London: Thames \& Hudson.

Lewis, C. S., \& Hooper, W. (2004). The collected letters of C.S. Lewis. San Francisco: Harper San Francisco.

Montgomery, J.W. (1974). Myth, Allegory, and Gospel: An Interpretation of JRR Tolkien, CS Lewis, GK Chesterton, Chas Williams. Bloomington, Minnesota: Bethany House.

Petty, A. C. (2002). One ring to bind them all: Tolkien's mythology. Tuscaloosa, Ala. [u.a.: Univ. of Alabama Press. Petty, A. C. (2003). Tolkien in the land of heroes: Discovering the human spirit. Cold Spring Harbor, NY: Cold Spring Press.

Purtill, R. L. (1984). J.R.R. Tolkien: Myth, morality, and religion. San Francisco: Harper \& Row.

Retrieved from http://www.jitterbug.com/origins/myth.html

Shippey, T. (2001). J.R.R. Tolkien: Author of the Century. Boston: Houghton Mifflin.

Shippey, T. (1992). The Road to Middle-earth. London: Grafton. 
Tolkien, J.R.R. (2004). The Lord of the Rings. Boston: Houghton Mifflin.

Tolkien, J.R.R. (1965). The Hobbit. New York: Ballantine Books.

Tolkien, J.R.R. (1977). The Silmarillion. Christopher Tolkien (Ed.). Boston: Houghton Mifflin.

Tolkien, J.R.R. (2007). The Children of Húrin. Christopher Tolkien (Ed.). Boston and New York: Houghton Mifflin.

Tolkien, J.R.R. (1987). The Lost Road and Other Writings. Christopher Tolkien (Ed.). London: Allen \& Unwin.

Tolkien, J.R.R. (1996). The Book of Lost Tales. Two Parts. The History of Middle-earth 1-2. Christopher Tolkien (Ed.).

London: Allen \& Unwin.

Tolkien, J.R.R. (1996). The Lays of Beleriand. Christopher Tolkien (Ed.). London: Allen \& Unwin.

Tolkien, J.R.R. (1986). The Shaping of Middle-earth. Christopher Tolkien (Ed.). London: Allen \& Unwin.

Tolkien, J.R.R. (2002). The Return of the Shadow. Christopher Tolkien (Ed.). London: Harper Collins.

Tolkien, J.R.R. (2001). The Treason of Isengard. Christopher Tolkien (Ed.). London: Harper Collins.

Tolkien, J.R.R. (1990). The War of the Ring. Christopher Tolkien (Ed.). Boston: Houghton Mifflin Company.

Tolkien, J.R.R. (2002). Sauron Defeated. Christopher Tolkien (Ed.). London: Harper Collins.

Vogler, Christopher. (2007). The writer's journey: Mythic structure for writers. Studio City, CA: M. Wiese Productions.

Zimbardo, R. A., Isaacs, N. D. (2004). Understanding The lord of the rings: The best of Tolkien criticism. Boston: Houghton Mifflin.

\section{Notes}

${ }^{\mathrm{i}}$ Brennan,2001

${ }^{\text {ii }}$ Campbell, The Hero with a Thousand Faces, 1966, p4

iii Joseph Campbell, The Hero with a Thousand Faces. kesti, T. Heroes of Middle-Earth: J. Campbell's Monomyth in J.R.R. Tolkien's The Lord of the Rings (1954-1955).Finland, 2007.

iv Tolkien says, "He had the sense of recording what was already 'there'...not of inventing." Letters of J.R.R. Tolkien, 145 [131, undated to Milton Waldman] also Verlyn Flieger, The Lord of the Rings, 1954-2004: Scholarship in Honor of Richard E. Blackwelder, pp. 283-299.2006

v Stanton, Michael N. "Frodo”. J.R.R. Tolkien Encyclopedia: Scholarship and Critical Assessment, Ed. Michael D.C. Drout. New York/London: Routledge, 2007. p 259.

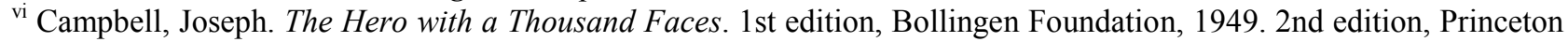
University Press. 3rd edition, New World Library, 2008, p 47.

vii Campbell, Joseph. The Hero with a Thousand Faces. 1st edition, Bollingen Foundation, 1949. 2nd edition, Princeton University Press. 3rd edition, New World Library, 2008, p 53.

viii Vogler, Christopher. The Writer's Journey: Mythic Structure For Writers. Studio City, CA: Michael Wiese Productions, 1998, P 100

ix Vogler, Christopher. The Writer's Journey: Mythic Structure For Writers. Studio City, CA: Michael Wiese Productions, 1998, p 10.

x Vogler, Christopher. The Writer's Journey: Mythic Structure For Writers. Studio City, CA: Michael Wiese Productions, 1998, p 56.

xi Vogler, Christopher. The Writer's Journey: Mythic Structure For Writers. Studio City, CA: Michael Wiese Productions, 1998, p 11.

xii Vogler, Christopher. The Writer's Journey: Mythic Structure For Writers. Studio City, CA: Michael Wiese Productions, 1998, p 108

xiii Tolkien, J.R.R. The Lord of the Rings. Fiftieth anniversary edition. Boston: Houghton Mifflin, 2004. P 289

${ }^{\text {xiv }}$ Tolkien, J.R.R. The Lord of the Rings. Fiftieth anniversary edition. Boston: Houghton Mifflin, 2004. P 290

${ }^{x v}$ Vogler, Christopher. The Writer's Journey: Mythic Structure For Writers. Studio City, CA: Michael Wiese Productions, 1998. P 12

${ }^{\mathrm{xvi}}$ Kesti, Tutta. Heroes of Middle-Earth: J. Campbell's Monomyth in J.R.R. Tolkien's The Lord of the Rings (19541955).॥ Thesis. University of jyväskylä, Finland, 2007.

${ }^{x v i i}$ Campbell, Joseph. The Hero with a Thousand Faces. 1st edition, Bollingen Foundation, 1949. 2nd edition, Princeton University Press. 3rd edition, New World Library, 2008. P 77-78

${ }^{x v i i i}$ Petty, A.C. One ring to bind them all: Tolkien's Mythology, university, 1979. P 33

xix Vogler, Christopher. The Writer's Journey: Mythic Structure For Writers. Studio City, CA: Michael Wiese Productions, 1998. P 13

xx Vogler, Christopher. The Writer's Journey: Mythic Structure For Writers. Studio City, CA: Michael Wiese Productions, 1998. P 12

${ }^{x x i}$ Campbell, Joseph. The Hero with a Thousand Faces. 1st edition, Bollingen Foundation, 1949. 2nd edition, Princeton University Press. 3rd edition, New World Library, 2008. P 63

xxii Campbell, Joseph. The Hero with a Thousand Faces. 1st edition, Bollingen Foundation, 1949. 2nd edition, Princeton University Press. 3rd edition, New World Library, 2008. P 63

xxiii Campbell, Joseph. The Hero with a Thousand Faces. 1st edition, Bollingen Foundation, 1949. 2nd edition, Princeton University Press. 3rd edition, New World Library, 2008. P 65

xxiv Burns, Marjorie. "Gandalf and Odin" In Tolkien's legendarium, edited by Verlyn Flieger and Carl Hostetter. Westport, CT: Greenwood, 2000.

xxv Helms, Randel. Tolkien's World, Boston, MA: Houghton Mifflin, 1974.

Tolkien, J.R.R. The Lord of the Rings. Fiftieth anniversary edition. Boston: Houghton Mifflin, 2004. 125 
${ }^{\mathrm{xxvi}}$ Anger Done N. “Glorfindel”. J.R.R. Tolkien Encyclopedia: Scholarship and Critical Assessment, Ed. Michael D.C. Drout. New York/London: Routledge, 2007, p 279

xxvii Some Christians consider almost impossible to prove such comparison, and some Tolkien scholars as well may question the veracity of such similarities and likeness; especially by referring to some of Galadriel's manners, such as her pride, or her rebellion against the Valar [the Angelic guardians] and her childbearing. However, some of Galadriel's key aspects make this analogy almost possible, and worthy of deeper reflections.

xxviii Shippey, T.A. The Road to Middle-earth, Boston: Houghton Mifflin, 2000. J.R.R. Tolkien Encyclopedia: Scholarship and Critical Assessment, p 263.

${ }^{x x i x}$ Flieger, Verlyn. Splintered Light: Logos and Language in Tolkien's World. 2nd ed. Kent, OH: Kent State University Press, 2002.

Fisher, Jason. "Phial”. J.R.R. Tolkien Encyclopedia: Scholarship and Critical Assessment, Ed. Michael D.C. Drout. New York/London: Routledge, 2007. P 543

${ }^{\mathrm{xxx}}$ Campbell, Joseph. The Hero with a Thousand Faces. 1st edition, Bollingen Foundation, 1949. 2nd edition, Princeton University Press. 3rd edition, New World Library, 2008. P 83

${ }^{\text {xxxi }}$ Kesti, Tutta. Heroes of Middle-Earth: J. Campbell's Monomyth in J.R.R. Tolkien's The Lord of the Rings (19541955).॥ Thesis. University of jyväskylä, Finland, 2007.

xxxii Campbell, Joseph. The Hero with a Thousand Faces. 1st edition, Bollingen Foundation, 1949. 2nd edition, Princeton University Press. 3rd edition, New World Library, 2008. P 84

xxxiii Campbell, Joseph. The Hero with a Thousand Faces. 1st edition, Bollingen Foundation, 1949. 2nd edition, Princeton University Press. 3rd edition, New World Library, 2008. P 89

xxiv Burns, Marjorie. Gandalf and Odin in Tolkien's Legendarium, edited by Verlyn Flieger and Carl Hostetter, Westport, CT: Greenwood, 2000.

${ }^{\mathrm{xxxv}}$ It was a strong substance used by the elves of Lothlórien, which was grey in color and felt silky to the touch. It was known to be used in the making of ropes, which were flexible and light, yet extremely robust. "Farewell to Lórien" Tolkien, J.R.R. The Fellowship of the Ring. Boston: Houghton Mifflin, 1954. Second edition published 1987.

xxxvi Campbell, Joseph. The Hero with a Thousand Faces. 1st edition, Bollingen Foundation, 1949. 2nd edition, Princeton University Press. 3rd edition, New World Library, 2008. P 105

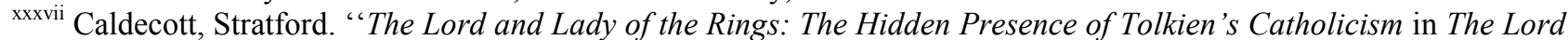
of the Rings.' Touchstone Magazine 15, no. 1 (January-February 2002).

Fisher. Jason. "Galadriel”. J.R.R. Tolkien Encyclopedia: Scholarship and Critical Assessment, Ed. Michael D.C. Drout. New York/London: Routledge, 2007. P 263

xxxviii Tolkien, J.R.R. The Fellowship of the Ring. Boston: Houghton Mifflin, 1954. Second edition published 1987. P 348.

Nancy Enright, Tolkien's Females and the Defining Power, From Renascence 59, no. 2 (Winter 2007): pp. 93-108.

${ }^{\mathrm{xl}}$ Tolkien, J.R.R. The Lord of the Rings. Fiftieth anniversary edition. Boston: Houghton Mifflin, 2004. P 40

xli Tolkien, J.R.R. The Lord of the Rings. Fiftieth anniversary edition. Boston: Houghton Mifflin, 2004. P 44

xlii Tolkien, J.R.R. The Fellowship of the Ring. Boston: Houghton Mifflin, 1954. Second edition published 1987. P 356

xliii Tolkien, J.R.R. The Lord of the Rings. Fiftieth anniversary edition. Boston: Houghton Mifflin, 2004. P 924

Kesti, Tutta. Heroes of Middle-Earth: J. Campbell's Monomyth in J.R.R. Tolkien's The Lord of the Rings (1954-1955).\| Thesis. University of jyväskylä, Finland, 2007

xliv Campbell, Joseph. The Hero with a Thousand Faces. 1st edition, Bollingen Foundation, 1949. 2nd edition, Princeton University Press. 3rd edition, New World Library, 2008. P150

${ }^{x l v}$ Burns, Marjorie. 'Gandalf and Odin.'” In Tolkien's Legendarium, edited by Verlyn Flieger and Carl Hostetter. Westport, CT: Greenwood, 2000.

Tolkien, J.R.R. The Fellowship of the Ring. Boston: Houghton Mifflin, 1954. Second edition published 1987. P 65

xlvii Jane Chance, "Queer" Hobbits: The Problem of Difference in the Shire, from The Lord of the Rings: the Mythology of Power, PP 26-37

xlviii Campbell, Joseph. The Hero with a Thousand Faces. 1st edition, Bollingen Foundation, 1949. 2nd edition, Princeton University Press. 3rd edition, New World Library, 2008. P 126

${ }^{x l i x}$ Luke, 6:27-36

${ }^{1}$ Campbell, Joseph. The Hero with a Thousand Faces. 1st edition, Bollingen Foundation, 1949. 2nd edition, Princeton University Press. 3rd edition, New World Library, 2008. P 159

${ }^{\text {li }}$ Campbell, Joseph. The Hero with a Thousand Faces. 1st edition, Bollingen Foundation, 1949. 2nd edition, Princeton University Press. 3rd edition, New World Library, 2008. P 175

lii Campbell, Joseph. The Hero with a Thousand Faces. 1st edition, Bollingen Foundation, 1949. 2nd edition, Princeton University Press. 3rd edition, New World Library, 2008. P 177

liii Tolkien, J.R.R. Return of the King. Boston: Houghton Mifflin, 1956. Second edition published 1987. P 145

liv Tolkien, to Milton Waldman, probably late 1951, in Letters, 144.

lv Tolkien, Tree and Leaf, 88-89.

lvi Vogler, Christopher. The Writer's Journey: Mythic Structure For Writers. Studio City, CA: Michael Wiese Productions, 1998. P 232.

lvii Vogler, Christopher. The Writer's Journey: Mythic Structure For Writers. Studio City, CA: Michael Wiese Productions, 1998. P 295. 